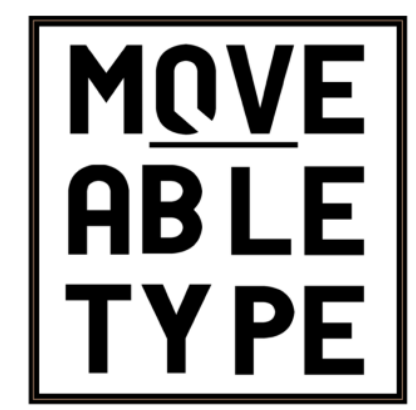

[Review] Unwatchable

Author[s]: Katie Arthur

Source: Moveable Type, Vol.11, 'Decadence' (2019)

DOI: $10.14324 / 111.1755-4527.101$

Moveable Type is a Graduate, Peer-Reviewed Journal based in the Department of English at UCL.

(C) 2019 Katie Arthur. This is an Open Access article distributed under the terms of the Creative Commons Attribution License (CC-BY) 4.0https://creativecommons.org/licenses/by/4.0/, which permits unrestricted use, distribution, and reproduction in any medium, provided the original author and source are credited. 


\title{
Bearing Witness
}

\section{Katie Arthur}

\author{
Unwatchable. \\ Eds. Nicholas Baer, Maggie Hennefeld, Laura Horak and Gunnar Iversen. 2019. \\ Viii+402p. \$29.95. Rutgers University Press. \\ ISBN 978-0-8135-9958-8
}

Spanning a variety of disciplines and social contexts, Unwatchable is an anthology that asks 'what does it mean to proclaim something "unwatchable": disturbing, revolting, poor, tedious or literally inaccessible? ${ }^{11}$ Rather than attempting to offer a single answer to this far-reaching question, the anthology comprises 54 separate critical pieces. This provides a multitude of perspectives with which one might begin analysing both personal and professional 'unwatchables', from Vivian Sobchack's reflections on looking at offscreen, oblique, or obscene space ${ }^{2}$; to Alex Bush's and J. Hoberman's respective discussions of the bodily limitations that constrain our physical capacity to watch. The act of watching and the designation of certain texts as unwatchable are constituted by the collection as political gestures of 'witnessing' for which we can all be held accountable, most elegantly articulated by Danielle Peers in her piece 'Unwitnessable: Outrageous Ableist Impersonations'.

The idiosyncratic format of the essays reflects the anthology editors' aims of presenting a collection that is simultaneously 'intimate and far-reaching.' Contributors were prompted to write unusually short essays (750 to 1,500 words) to make the "small forms" "that constitute the anthology. ${ }^{3}$ Whilst the shorter length seems to sometimes steer contributors into the anecdotal, the 'dispensing' of 'distanced analysis' creates space for the personal, the political, and even the humorous. ${ }^{4}$ The 15 chapters rove across terrain as diverse as 'Reality Trumpism' and 'Pedagogy and Campus Politics', positioning the anthology as a rejoinder to the contemporary political climate in the United States.

The editors' introduction provides a genealogy of 'unwatchability' from Plato and Aristotle's disagreement over the value of mimetic art, through the iconoclasm of various monotheistic religions, and finally to the inauguration of scholarly studies of visual culture in the 1990s. Whilst the editors' mapping of the various critical perspectives lends itself to

1 Nicholas Baer, Maggie Hennefeld, Laura Horak, Gunnar Iversen, 'Introduction,' Unwatchable, ed. by Nicholas Baer, Maggie Hennefeld, Laura Horak, and Gunnar Iversen (London: Rutgers University Press, 2019), pp. 1-29 (p. 3).

2 Vivian Sobchack, “'Peekaboo:” Thoughts on (Maybe Not) Seeing Two Horror Films,' Unwatchable, pp. 201-206 (p. 203).

3 Baer, Hennefeld, Horak, Iversen, 'Introduction', p. 19.

4 Ibid. 
a cover-to-cover reading, the anthology can also be read rhizomatically. Rather than broadly surveying the multifaceted histories and various cultural uses of the unwatchable, the range of interventions and entry-points are independently useful to the visual studies researcher.

Beginning with 'Violence and Testimony', Unwatchable's opening section is its most diverse, starting with a series of theorizations of the unwatchable that span Hegelian aesthetics, Buchenwald, and the television series Black Mirror. Exploring how violence defies or is compounded through visual representation, the section cites examples from contemporary political issues such as climate change, race, gender, sexuality, and ability. Emily Regan Willis provides an urgent pause on the arresting images of the refugee crisis in her essay 'Alan Kurdi's Body on the Shore', while Alec Butler considers how one's unwatchable can become another's fancy dress costume in 'Holocausts, Hallowe'en, and Headdresses.' The anthology gives space throughout to address the intersection of violence with sexist, colonialist, and ableist discourse, particularly in the subsection 'Spectacularization and Resistance.'

Among Unwatchable's critical attention to race, Jared Sexton's 'The Flash of History: On the Unwatchable in Get Out' provides a method to engage with director Jordan Peele's representations of Black embodiment and modes of seeing. By focusing on the films' utilisation of the surreal and uncanny the piece creates space for further critical responses to other recent pop-culture examples of a turn to Afro-surrealism ${ }^{5}$ to represent Black American experiences, such as Donald Glover's television series Atlanta ${ }^{6}$ and Boots Riley's 2018 film Sorry to Bother You. Baring those moments that eyes cannot bear to see creates a gaze that is both unflinching and claustrophobic, showing only some of us have the privilege of averting our eyes from the unwatchable.

Part II, 'Histories and Genres', offers glimpses into the unwatchable in cinematic history. Covering infamous 'cine-nasties' as well as horror classics, this section also explores potentially alternative economies of consumption and (re)production posed by avant-garde film, pornography, and archive film. For instance, Erika Balsom's 'Watching Paint Dry' convincingly weaves a range of avant-garde examples to reflect on duration and spectatorial endurance as resisting notions of productivity under a capitalist structuring of time and leisure.

\footnotetext{
5 Lanre Bakare, 'From Beyoncé to Sorry to Bother You: the new age of Afro-surrealism,' The Guardian, 6 Dec. 2018, <theguardian.com/tv-and-radio/2018/dec/06/afro-surrealism-black-artists-racist-society> [accessed 4 February 2019]

6 Evan Higgins, 'Atlanta's surrealism and the black experience in America,' Slate, 27 Feb 2018,

< slate.com/culture/2018/02/atlantas-surrealism-and-the-black-experience-in-america.html > [accessed 4 Feb 2019]
} 
Part III, 'Spectators and Objects', shifts critical focus to viewing and reception. The first section, 'Passionate Aversions' injects some welcome instances of levity into the collection. Wryly funny entries are Jonathan Rosenbaum's “'Sad!”: Why I Won’t Watch Antichrist', which scathingly castigates Lars Von Trier's' auteurial nihilism as sadistic, disempowering, and misogynistic; and Nathan Lee's polemic on the Nietzschean logic encoded in the Transformers movie series. However, the sections that follow, 'Tedious Whiteness' and 'Reality Trumpism', serve as impassioned indictments of the current US political moment, returning the reader to a more serious focus.

Perhaps above all else, the anthology points to the sitting US president Donald Trump as an unreconciled and potentially unreconcilable phenomenon both within the US and beyond. Many essays trace 'Trumpism' (shorthand for both growing political polarization, and a growing political and cultural impetus against so-called 'political correctness') as lurking beneath the surface of socio-political discourse, rendering itself unwatchable until its stark unveiling in the 2016 US presidential election.

The final essay in the collection, Rebecca Schneider's 'Off Watch', speaks to this point through an account of a small, invisible parasite that renders her young sister blind. Perhaps the unwatchable seems particularly relevant for this political climate not only because of what we cannot bear to see, but for what we choose not to watch.

[] f we can't necessarily watch for unwatchables (because they catch us off watch), how do we begin to let them in otherwise? ... If we, or our sisters, have (been) failed on our watch, can we still sound an anachronistic alarm and turn that watch into a matter of witness? ${ }^{7}$

Unwatchable asserts that the current political moment was unseen until too late, left unchecked and unexamined until the effect of its cause was already in office. As a whole, the tone of the writing is refreshing-sometimes experimental and at others painfully reflective. Readers embark on deeply personal and highly politicised journeys with contributors, recalling harrowing moments from cinematic, televisual, world, and personal history. Perhaps most crucially it also amplifies the voices of those who have no choice but to be watchful, even during a period of what seemed to some to be political calm.

Katie Arthur

King's College London katie.arthur@kcl.ac.uk

7 Rebecca Schneider, 'Off Watch,' Unwatchable, pp. $341-346$ (p. 345). Schneider's italicisation. 